\title{
Study of Heavy Metal Uptake by the Crops Grown by Using Urban Wastewater of Mysore City, India
}

\author{
Mavinakere Ramesh Abhilash, Shivanna Srikantaswamy*, Doddaiah Shiva Kumar, \\ Budiguppe Mahadevaiah Kiran \\ Department of Studies in Environmental Science, University of Mysore, Mysore, India \\ Email: srikantas@hotmail.com
}

Received 30 May 2014; revised 28 June 2014; accepted 21 July 2014

Copyright (C) 2014 by authors and Scientific Research Publishing Inc.

This work is licensed under the Creative Commons Attribution International License (CC BY).

http://creativecommons.org/licenses/by/4.0/

c) (i) Open Access

\begin{abstract}
In the $21^{\text {st }}$ century the fresh water scarcity increased very rapidly due to the urbanization and industrialization process. In these conditions the urban wastewater plays an important role in the water usage criteria. In this aspect, in all the major cities, wastewater treatment plants have been constructed to treat the urban wastewater in view of decreasing the water scarcity. The presence of nutrients in the wastewater is considered as beneficial to agricultural practices. The contaminants present in the wastewater pose health risks directly to agricultural workers and indirectly to the consumers as the long term application of the wastewater may result in the accumulation of toxic elements in soil and in plants. In this way the heavy metals will circulate among the food chain and food web to cause adverse effects on human health as well as on soil health. In the present study an attempt has been made to study the characteristics of urban wastewater at wastewater treatment plant of Mysore city. And also heavy metal behavior was studied with the analysis of heavy metals in wastewater, Biosolid and receiving soil along with the plants which indicates the uptake of heavy metals.
\end{abstract}

\section{Keywords}

Urban Wastewater (UWW), Biosoild, Heavy Metal, Bio-Accumulation, Mysore

\section{Introduction}

Water is one of the important natural resources of the planet earth and essential for the survival of all forms of

"Corresponding author.

How to cite this paper: Abhilash, M.R., Srikantaswamy, S., Kumar, D.S. and Kiran, B.M. (2014) Study of Heavy Metal Uptake by the Crops Grown by Using Urban Wastewater of Mysore City, India. Journal of Environmental Protection, 5, 1169-1182. http://dx.doi.org/10.4236/jep.2014.512114 
life. Water is one of the greatest looming commodities of the $21^{\text {st }}$ century. It underpins all aspects of human society, from ecology to agriculture to industry and it has no known substitutes. An appreciable part of it gets lodged in snowcaps and natural lakes and is subsequently utilizable, in case of the former through snowmelt reaching a river system. A sizeable part is retained in surface soils and used up through evapotranspiration for biomass generation. Another part seeps into the ground feeding natural aquifers. A major part appears in the river system downstream and is drained into seas, unless it is captured in man-made storages or artificially diverted from natural courses. Water is recycled continuously through transpiration and evaporation from land, river systems and oceans, besides precipitation through condensation, rain and snow.

According to the United Nation's World Water Development Report (2003) [1], 70 per cent of the earth's surface is covered by water, but only 2.5 per cent of that water is fresh and a fraction of it i.e. 0.3 per cent of that water only is available for human use. If per capita consumption of water resources continues to rise at its current rate, humankind could be using over 90 per cent of all available freshwater within 25 years, leaving just 10 per cent for all other organisms [1].

\section{Water Pollution}

In the developing countries, $80 \%$ of all diseases are directly related to poor quality of drinking water and unsanitary conditions [2]. The industrial units located at the outskirts in cities, intensive agricultural practices and indiscriminate disposal of domestic and municipal wastes are the sources for water pollution. Thus constant monitoring of river water is needed so as to record any alteration in the quality and outbreak of health disorders. In India it is reported that about $70 \%$ of the available water is polluted. The chief source of pollution is identified as sewage constituting $84 \%$ to $92 \%$ of the wastewater. Industrial wastewater comprised $8 \%$ to $16 \%$.

Most widespread pollution is the discharge of urban wastewater into natural water. It has been reported that 50 to 70 per cent pollution load of rivers, lakes and ponds is from urban wastewater.

Urban lakes and ponds are highly degraded due to direct entry of urban wastewater from the intensively urbanized catchment areas. The most obvious effect of release of untreated urban or industrial wastewaters into rivers is significant decline in dissolved oxygen concentration and rise in ammonia and nitrogen concentrations.

\section{Irrigation with Urban Wastewater}

Land application of wastewater, sludge and excreta on land is a widespread practice with a long tradition in many countries around the world. Wastewater and sewage sludge, just as manure, have also been used by the northern European and Mediterranean civilizations, and also wastewater was reused in the $14^{\text {th }}$ and $15^{\text {th }}$ centuries in the Milanese Marcites and in the Valencian huertas, respectively [3]. In many European and North American cities, wastewater was disposed of in agricultural fields before the introduction of wastewater treatment technologies to prevent pollution of water bodies. In developing countries like China, Mexico, Peru, Egypt, Lebanon, Morocco, India and Vietnam, wastewater has been used as a source of crop nutrients over many decades [4] [5]. Therefore, agricultural use of untreated wastewater has been associated with land application and crop production for centuries [6]. However, over the years, it has become less popular in developed countries with the improvement of treatment technologies and increased awareness of the environmental and health issues associated with the practice.

\section{Materials and Methods}

\subsection{Study Area}

The study area Mysore is a unique city having around 12 lakh population and was capital of former princely state of Karnataka. It lies between $12^{\circ} 9^{\prime}$ and $11^{\circ} 6^{\prime}$ latitude and $77^{\circ} 7^{\prime}$ longitude and general elevation is little more than 1800 feet above sea level. The climate of the city is moderated throughout the year with temperature during summer ranging from $30^{\circ} \mathrm{C}$ to $34^{\circ} \mathrm{C}$. The rainy season is from May to October. The winter season is from November to February. The source of water for domestic and industrial purpose is mainly from the Cauvery River and ground water.

In recent years industrialization has become main cause of city's growth. There is diversity in industrial landscape of Mysore with haphazard distribution. The industrial areas are distributed all over the city and its surroundings with lack of order and regulation in industrial location. A large number of small medium and large 
scale industries exists in and around the Mysore city, including engineering, chemical, pharmaceutical, food, brewery, distillery, textile, steel and metal smelting.

Mysore has adequate water supply resources due to the proximity of Rivers Cauvery and Kapila. The topography of the city is such that the entire UWW drains into three valleys viz., northern out-fall into Kesare Valley, and other outfalls to the south one into Dalvai tank feeder valley and another to Malalavadi tank valley as shown in Figure 1.

Mysore was one of the earliest cities in India to have underground drainage. In old parts of the city, underground drainage was completed in 1904. The quantity of domestic wastewater generated has increased from 80 MLD during 2001 to 128 MLD during 2006-07. The area covered with sewer system is $100 \mathrm{sq} . \mathrm{km}$ and the total length of sewer lines is $740 \mathrm{~km}$. Only about $57 \%$ of the household are connected to underground drainage system.

Based on the topography of the city, Mysore city comprises of five drainage districts, namely, A, B, C, D and E districts respectively, covering different areas. The city has been provided with three wastewater treatment plants. Drainage districts of A \& D have the wastewater treatment plant of capacity 60.0 MLD, which is located at Rayankere, H. D. Kote Road, Mysore. The treatment plant for drainage district B is of capacity 67.65 MLD, which is located at sewage Farm, Vidyaranyapuram, Mysore. The treatment plant for drainage district $\mathrm{C}$ is of capacity 30.0 MLD, which is located at Kesare Village, Mysore. The wastewater from point source and non point sources from different areas of the drainage districts are collected in wet wells and treated in the wastewater treatment plants. All the treatment plants have facultative aerated lagoons and sedimentation basins. The process of primary treatment involves simple lagooning and subsequently natural oxidation where by the suspended colloidal particles of the UWW get partly or wholly coagulated and flocculated.

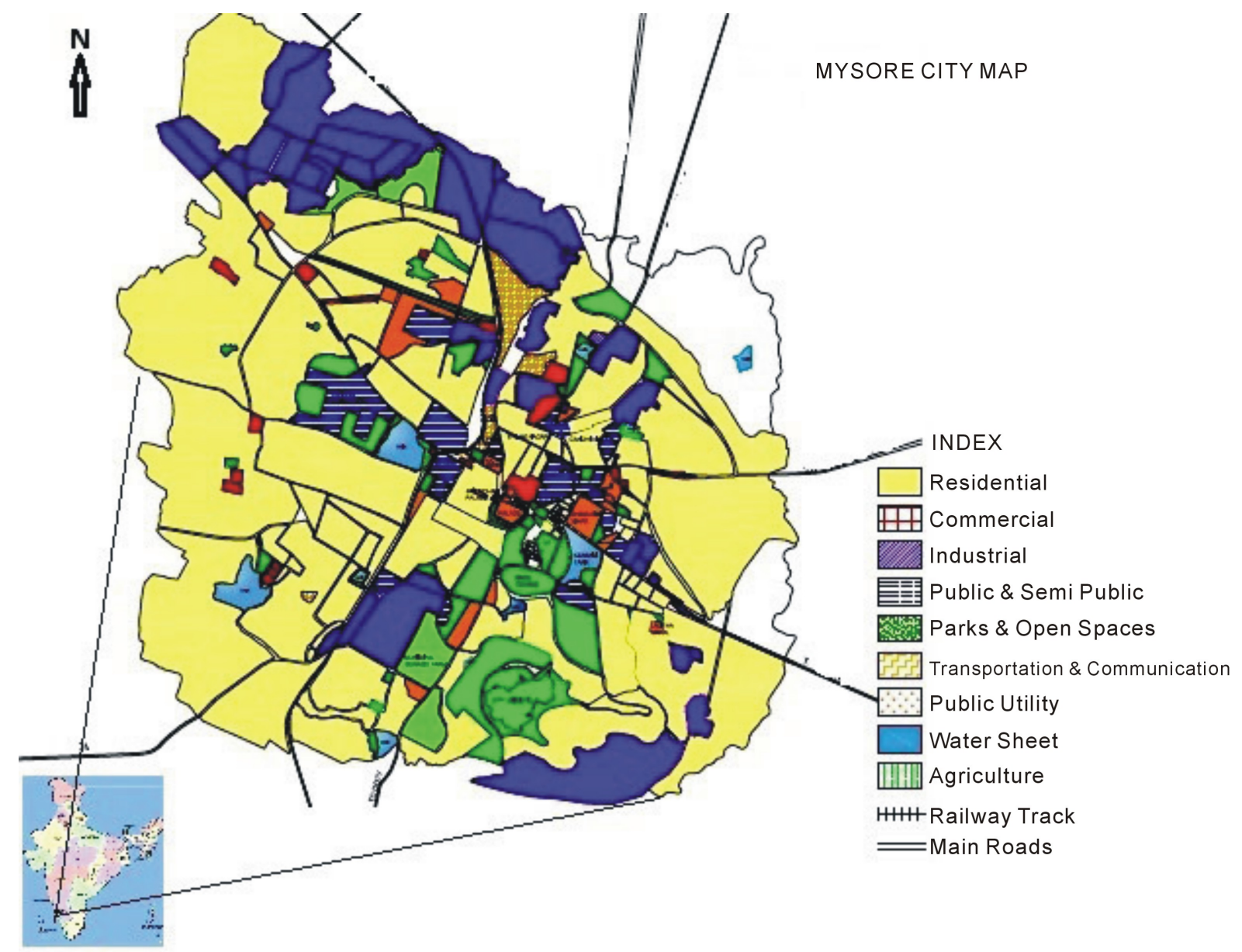

Figure 1. Urban wastewater treatment plants located in Mysore city, India. 
The fifth drainage district $\mathrm{E}$ in the city covers an area around $16 \mathrm{sq}$. km and at present, this district does not have a sewerage system. There are several missing links at each district and 3 MLD is discharged as such on land, in low lying areas, which joins water bodies. The missing sewer lines identified in the above mentioned drainage districts are of varying diameters differing from $150 \mathrm{~mm}$ to $900 \mathrm{~mm}$. The total length of missing sewer line identified as of 2012-13 is about 22,135 meter. The quantity of sewage generated is 125 MLD and 95 MLD is treated at wastewater treatment plants. The untreated and treated UWW is largely used for irrigation.

\subsection{Sampling and Analysis}

Sampling Stations: The following three sampling stations were selected for the present study located at wastewater treatment plants.

1) Kesare Village, Mysore.

2) Sewage Farm, Vidyaranyapuram, Mysore.

3) Rayankere, H. D. Kote Road, Mysore.

Due to scarcity of fresh water enormous quantity of UWW is being discharged without any treatment for agriculture purpose. The biosolids generated from the wastewater treatment plant are using as manure for agriculture field. Hence it is of importance to study the characteristic of the UWW and biosolids.

\subsection{Sample Collection}

UWW samples from three the location of the sampling stations were collected during 2013-14 in two litres capacity polyethylene cans. All the samples were transported to laboratory and stored at $4^{\circ} \mathrm{C}$. The separate samples of untreated and treated UWW samples of one litre capacity in polyethylene cans were collected for heavy metal analysis and preserved by adding $2 \mathrm{ml}$ of concentrated nitric acid to prevent precipitation of metals and growth of algae.

\subsection{Biosolid/Soil Samples/Plant Samples}

The biosolids collected for analysis is generated from three wastewater treatment plants of the samplings stations and amended soil samples were collected at different locations of study area with the plant species which grown by farmers by using the biosolids and UWW.

\subsection{Sample Preservation and Storage}

Samples can change very rapidly due to its high reactivity nature. However, no single preservation method will serve for all samples and constituents, so the purpose of sample preservation is to minimize any physical, chemical, and/or biological changes that may take place in a sample from the time of sample collection to the time of sample analysis. The addition of chemicals is essential to some parameters for their losses due to chemical reaction and bacterial degradation. Chemical addition or $\mathrm{pH}$ change can also be effective to reduce metal adsorption to glass container walls.

The samples were analyzed to know the characteristics of physico-chemical parameters of the UWW with the following parameters $\mathrm{pH}$, Electrical Conductivity (EC), Biochemical Oxygen, Demand (BOD5), Chemical Oxygen Demand (COD), Total Dissolve Solids (TDS), Suspended Solids (SS), Nitrate ( $\mathrm{NO}^{3}-\mathrm{N}$ ), Phosphate $\left(\mathrm{PO}_{4}^{3-}\right)$, Potassium $\left(\mathrm{K}^{+}\right)$.

\section{Results}

The untreated wastewater samples along with the biosolid and the plants which were grown by using the wastewater and its rooted soil has been analyzed and the results were tabulated in the Tables 1-8.

\section{Discussion}

\section{1. $\mathrm{pH}$}

$\mathrm{pH}$ is the hydrogen ion concentration and is an indicator of the acidity or basicity of water. It is the most important test used to study the water chemistry. Practically every phase of water supply and wastewater treatment 
Table 1. Physico-chemical and biological characteristic of UWW is used for irrigation in March 2013-14.

\begin{tabular}{ccccc}
\hline Sl. No. & Parameters & Kesare & Vidyaranyapuram & Rayanakere \\
\hline 1 & $\mathrm{pH}$ & 8.62 & 7.96 & 7.76 \\
2 & E. Cond (ds/m) & 1.190 & 1.313 & 0.923 \\
3 & $\mathrm{COD}(\mathrm{mg} / \mathrm{L})$ & 445.0 & 488.0 & 494.0 \\
4 & $\mathrm{BOD}(\mathrm{mg} / \mathrm{L})$ & 135.0 & 135.0 & 18.0 \\
5 & $\mathrm{TDS}(\mathrm{mg} / \mathrm{L})$ & 600 & 700 & 780 \\
6 & SS (mg/L) & 300 & 120 & 40 \\
7 & Nitrate (mg/L) & 0.04 & 0.2 & 0.32 \\
8 & Phosphate (mg/L) & 13.57 & 7.63 & 8.33 \\
9 & Potassium (mg/L) & 40 & 34 & 17 \\
\hline
\end{tabular}

Table 2. Heavy metal concentration in UWW, bio-solids, soil, used to grow plants during March-2014: Kesare urban wastewater treatment plant.

\begin{tabular}{cccccccc}
\hline Sl. No. & Sample reference & $\mathrm{Cd}$ & $\mathrm{Cu}$ & $\mathrm{Fe}$ & $\mathrm{Ni}$ & $\mathrm{Pb}$ & $\mathrm{Zn}$ \\
\hline 1 & Urban wastewater (mg/L) & $\mathrm{BDL}$ & 0.07 & 1.58 & 0.73 & 0.03 & 0.29 \\
2 & Biosolids (mg/Kg) & BDL & 0.05 & 37.1 & 0.72 & 0.2 & 1.48 \\
3 & Soil $(\mathrm{mg} / \mathrm{Kg})$ & $\mathrm{BDL}$ & 244.7 & 1583.4 & 399.2 & 21.5 & 342.6 \\
\hline
\end{tabular}

Note: All the heavy metals expressed in $\mathrm{mg} / \mathrm{Kg}$ except Fe (gm/Kg).

Table 3. Uptake of heavy metal concentration in plant species irrigated with UWW in Kesare urban wastewater treatment plant.

\begin{tabular}{ccccccccc}
\hline Sl. No & Name of plant species & Family & $\mathrm{Cd}$ & $\mathrm{Cu}$ & $\mathrm{Fe}$ & $\mathrm{Ni}$ & $\mathrm{Pb}$ & $\mathrm{Zn}$ \\
\hline 1 & Amaranthus tritis & Amaranthaceae & $\mathrm{BDL}$ & 0.1 & 155.9 & 0.83 & $\mathrm{BDL}$ & 2.67 \\
2 & Anethum graveolens & Apiaceae & $\mathrm{BDL}$ & 0.6 & 168.2 & 0.70 & $\mathrm{BDL}$ & 1.33 \\
3 & Coriandrum sativum & Apiaceae & $\mathrm{BDL}$ & 0.1 & 123.3 & 0.56 & $\mathrm{BDL}$ & 0.66 \\
4 & Mentha langifolia & Lamiacea & $\mathrm{BDL}$ & 0.1 & 151.4 & 0.32 & $\mathrm{BDL}$ & 0.78 \\
5 & Oryza sativa & Poaceae & $\mathrm{BDL}$ & 0.2 & 201.3 & 0.87 & $\mathrm{BDL}$ & 2.1 \\
6 & Spiracia oleracea & Amaranthaceae & $\mathrm{BDL}$ & 0.9 & 154.5 & 0.64 & $\mathrm{BDL}$ & 0.83 \\
7 & Trigonella foenum graecum & Fabaceae & BDL & 0.2 & 155.8 & 0.89 & BDL & 3.2 \\
8 & P. purpureum & Poaceae & BDL & 6.3 & 683.1 & 8.2 & 4.6 & 46.5 \\
\hline
\end{tabular}

Table 4. Heavy metal concentration in UWW, bio-solids, soil, used to grow plants during March-2014: Vidyaranyapuram urban wastewater treatment plant.

\begin{tabular}{cccccccc}
\hline Sl. No. & Sample reference & $\mathrm{Cd}$ & $\mathrm{Cu}$ & $\mathrm{Fe}$ & $\mathrm{Ni}$ & $\mathrm{Pb}$ & $\mathrm{Zn}$ \\
\hline 1 & Urban wastewater $(\mathrm{mg} / \mathrm{L})$ & $\mathrm{BDL}$ & 0.09 & 0.94 & 0.33 & 0.04 & 0.52 \\
2 & Biosolids $(\mathrm{mg} / \mathrm{Kg})$ & $\mathrm{BDL}$ & 0.07 & 19.1 & 0.64 & 0.3 & 0.70 \\
3 & Soil $(\mathrm{mg} / \mathrm{Kg})$ & $\mathrm{BDL}$ & 170.0 & 1330.9 & 138.3 & 16.4 & 287.6 \\
\hline
\end{tabular}

Table 5. Uptake of heavy metal concentration in plant species irrigated with UWW in Vidyaranyapuram urban wastewater treatment plant.

\begin{tabular}{ccccccccc}
\hline Sl. No. & Name of plant species & Family & $\mathrm{Cd}$ & $\mathrm{Cu}$ & $\mathrm{Fe}$ & $\mathrm{Ni}$ & $\mathrm{Pb}$ & $\mathrm{Zn}$ \\
\hline 1 & Anethum graveolens & Apiaceae & BDL & 0.09 & 140.2 & 0.90 & $\mathrm{BDL}$ & 0.90 \\
2 & Coriandrum sativum & Apiaceae & BDL & 0.07 & 119.1 & 0.78 & BDL & 0.60 \\
3 & Oryza sativa & Poaceae & BDL & 0.3 & 165.4 & 2.0 & BDL & 0.79 \\
4 & Spiracia oleracea & Amaranthaceae & BDL & 0.06 & 106.9 & 0.81 & BDL & 2.3 \\
5 & Trigonella foenum graecum & Fabaceae & BDL & 0.1 & 116.1 & 0.1 & BDL & 1.84 \\
6 & Zeamays & Poaceae & BDL & 1.5 & 251.3 & 3.2 & BDL & 3.5 \\
7 & P. purpureum & Poaceae & BDL & 5.0 & 412.2 & 7.8 & 3.6 & 30.2 \\
\hline
\end{tabular}

Note: All the heavy metals expressed in $\mathrm{mg} / \mathrm{Kg}$ except Fe (gm/Kg). 
Table 6. Heavy metal concentration in UWW, bio-solids, soil, used to grow plants during March-2014: Rayanakere urban wastewater treatment plant.

\begin{tabular}{cccccccc}
\hline Sl. No. & Sample reference & Cd & $\mathrm{Cu}$ & $\mathrm{Fe}$ & $\mathrm{Ni}$ & $\mathrm{Pb}$ & $\mathrm{Zn}$ \\
\hline 1 & Urban wastewater $(\mathrm{mg} / \mathrm{L})$ & BDL & 0.04 & 1.36 & 0.39 & 0.04 & 0.67 \\
2 & Biosolids $(\mathrm{mg} / \mathrm{Kg})$ & BDL & BDL & 17.1 & 0.32 & 0.10 & 0.98 \\
3 & Soil $(\mathrm{mg} / \mathrm{Kg})$ & BDL & 113.9 & 919.2 & 103.7 & 9.58 & 138.9 \\
\hline
\end{tabular}

Table 7. Uptake of heavy metal concentration in plant species irrigated with UWW in Rayanakere urban wastewater treatment plant.

\begin{tabular}{ccccccccc}
\hline Sl. No. & Name of plant species & Family & $\mathrm{Cd}$ & $\mathrm{Cu}$ & $\mathrm{Fe}$ & $\mathrm{Ni}$ & $\mathrm{Pb}$ & $\mathrm{Zn}$ \\
\hline 1 & Anethum graveolens & Apiaceae & $\mathrm{BDL}$ & 0.09 & 109.7 & 0.52 & $\mathrm{BDL}$ & 2.57 \\
2 & Coriandrum sativum & Apiaceae & $\mathrm{BDL}$ & 0.07 & 86.2 & 0.39 & $\mathrm{BDL}$ & 0.8 \\
3 & Oryza sativa & Poaceae & $\mathrm{BDL}$ & 2.6 & 177.1 & 0.87 & $\mathrm{BDL}$ & 1.2 \\
4 & Trigonella foenum graecum & Fabaceae & $\mathrm{BDL}$ & 0.6 & 100.4 & 0.63 & $\mathrm{BDL}$ & 0.70 \\
5 & P. purpureum & Poaceae & $\mathrm{BDL}$ & 4.9 & 57.3 & 4.9 & $\mathrm{BDL}$ & 40.3 \\
\hline
\end{tabular}

Table 8. Plant species that are grown using urban wastewater in Mysore city.

\begin{tabular}{|c|c|c|c|c|c|}
\hline \multirow{2}{*}{ Sl. No } & \multirow{2}{*}{ Name of plant species irrigated using UWW } & \multirow{2}{*}{ Family of the species } & \multicolumn{3}{|c|}{ UWW irrigated areas } \\
\hline & & & Kesare & Vidyaranyapuram & Rayanakere \\
\hline 01 & Amaranthus tritis & Amaranthaceae & + & & \\
\hline 02 & Anethum graveolens & Apiaceae & - & + & + \\
\hline 03 & Coriandrum sativum & Apiaceae & + & + & + \\
\hline 04 & Mentha longifolia & Lamiacea & + & _ & _- \\
\hline 05 & Oryza sativa & Poaceae & + & + & + \\
\hline 06 & Spiracia oleracea & Amaranthaceae & + & + & _ \\
\hline 07 & Trigonella foenum graecum & Fabaceae & + & + & + \\
\hline 08 & Zea mays & Poaceae & - & + & - \\
\hline 09 & P. purpureum & Poaceae & + & + & + \\
\hline & Total number of Species & & 08 & 07 & 05 \\
\hline
\end{tabular}

such as acid-base neutralization, water softening, precipitation, coagulation, disinfection and corrosion control depends on $\mathrm{pH}$.

It has been observed that the pH concentrations of the UWW used for irrigation sample are higher in the study area which may be attributed due to petrifaction and decomposition of organic matter. High carbonates and bi-carbonates cause Calcium and Magnesium ions to form insoluble minerals leaving Sodium as the dominant ion in solution. Highly alkaline water can intensify sodic soil conditions, which will have implications for agriculture.

The $\mathrm{pH}$ analysis of untreated UWW used for irrigation shows a maximum of 8.62 at Station No. 1 and minimum of 7.76 at Station No. 3 as shown in Figure 2. Slightly alkaline pH could be attributed to the detergents present in UWW and in cases of alkalinity due to the industrial effluent, and may be food stuff from domestic sources [7].

\subsection{Electrical Conductivity (EC)}

Electrical conductivity (EC) is a measure of the ions present in water, the conductivity increases with the increase of ions. It is also effectively a surrogate for Total dissolved Solids (TDS) and is important for irrigation because it is a measure of the salinity of the water.

The Electrical conductivity of untreated UWW used for irrigation shows $0.923 \mathrm{dS} / \mathrm{m}$ at Station No. 3 to 1.313 $\mathrm{dS} / \mathrm{m}$ in Station No. 2. The EC values of untreated UWW used for irrigation at three locations lie within the FAO irrigation water quality standards and shown in Figure 3. 
$\mathrm{pH}$

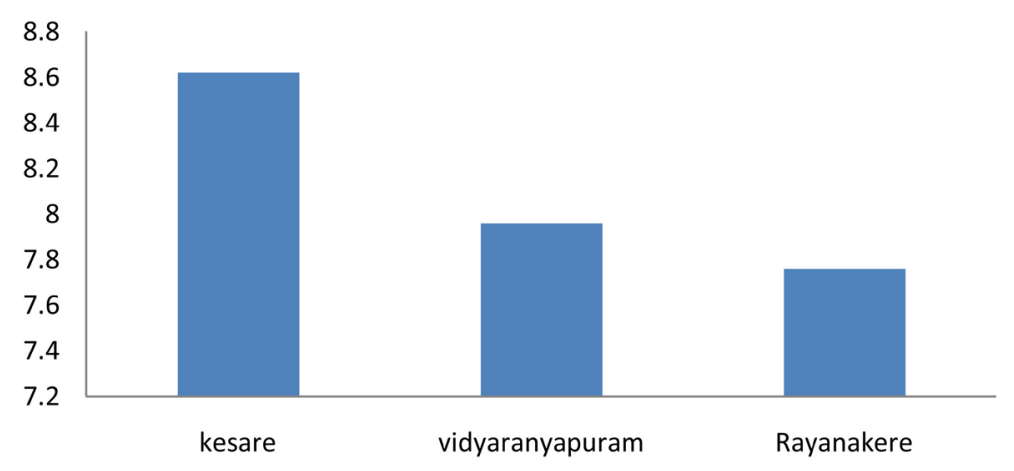

Figure 2. pH of urban wastewater treatment plants.

$E C(d s / m)$

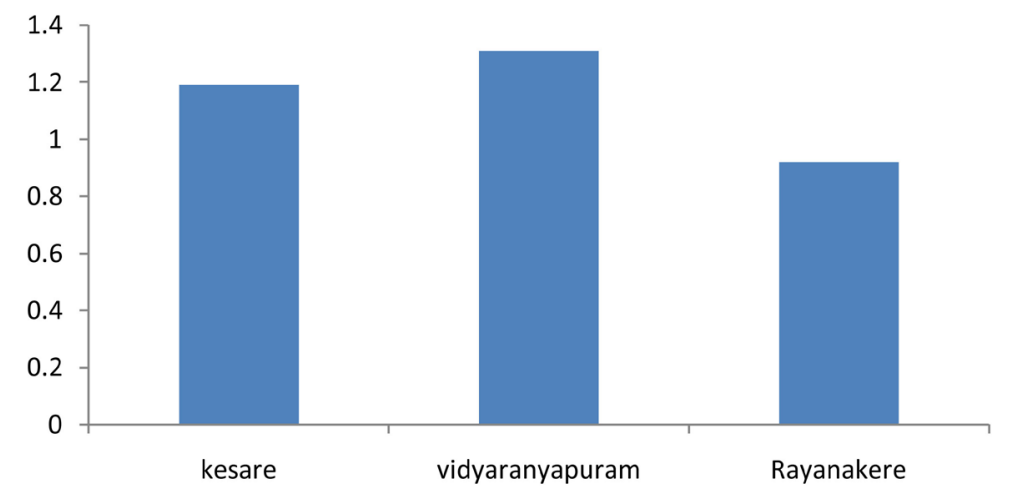

Figure 3. EC of urban wastewater treatment plants.

\subsection{Total Dissolved Solids (TDS)}

TDS refer to the matter suspended or dissolved in water or wastewater. Solids may affect waste and or effluent quality adversely. A constant level of minerals in the water is necessary for aquatic life. Concentrations of total dissolved solids that are too high or too low may have limited the growth and lead to the death of many aquatic life forms.

The TDS of untreated UWW used for irrigation shows range between $600 \mathrm{mg} / \mathrm{L}$ at station No. 1 to $780 \mathrm{mg} / \mathrm{L}$. at Station No. 3. The Site No. 3 has more TDS, which is understandable because suspended materials along with the salts are not settled completely. Excessive total salt concentration or excessive levels of some potentially toxic elements can have detrimental effects on plant health and soil conditions. The concentration of TDS of untreated wastewater was graphically represented in Figure 4.

\subsection{Chemical Oxygen Demand (COD)}

The COD test is used to measure the oxygen equivalent of the organic material in wastewater that can be oxidized chemically using dichromate in acid solution.

During the study period the concentration of COD in the untreated UWW used for irrigation ranged between $445.0 \mathrm{mg} / \mathrm{L}$ to $494.0 \mathrm{mg} / \mathrm{L}$. COD showed a trend of high concentration in all the stations of Mysore due to the scarcity of water and release of more industrial effluent to the UWW and shown in Figure 5. CPCB has recommended $250 \mathrm{mg} / \mathrm{L}$ for discharge of wastewaters on land for irrigation; the treated samples are within the standards.

\subsection{Nitrate $\left(\mathrm{NO}_{3}-\mathrm{N}\right)$}

$\mathrm{NO}_{3}-\mathrm{N}$ is a necessary primary macronutrient for plants that stimulates plant growth and is usually added as a 
$\operatorname{TDS}(\mathrm{mg} / \mathrm{l})$

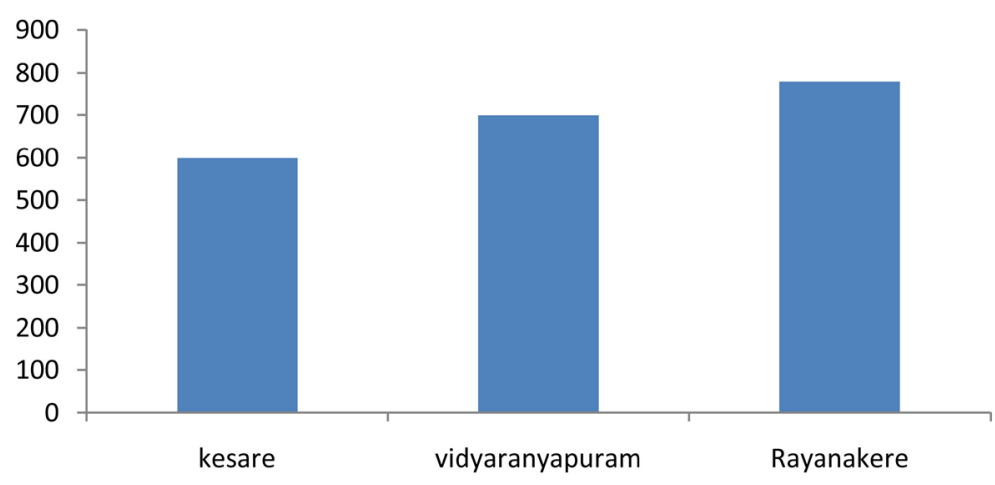

Figure 4. TDS of urban wastewater treatment plants.

$\operatorname{COD}(\mathrm{mg} / \mathrm{l})$

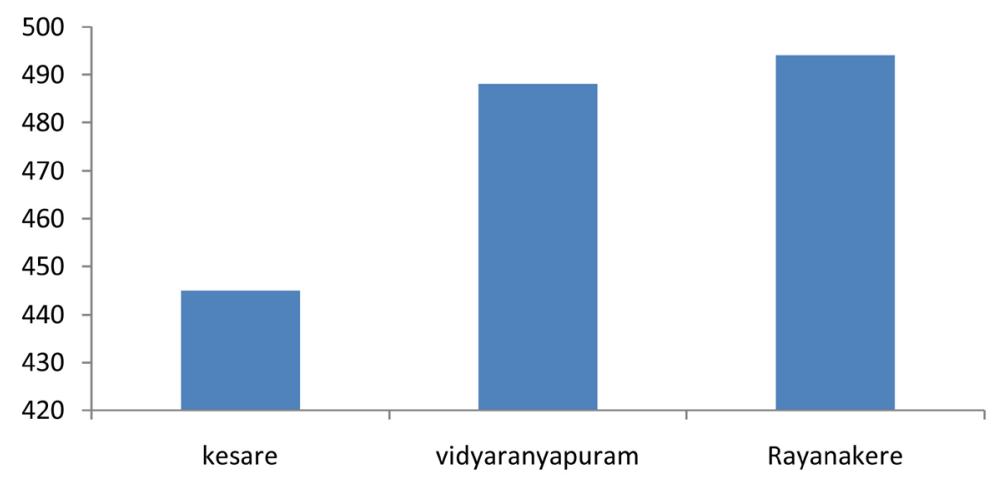

Figure 5. COD of urban wastewater treatment plants.

fertilizer but can also be found in wastewater as nitrate, ammonia, organic nitrogen or nitrite [8].

The Nitrate of untreated UWW used for irrigation ranged between $0.04 \mathrm{mg} / \mathrm{L}$ at Station No. 1 to $0.32 \mathrm{mg} / \mathrm{L}$ at Station No. 3 in March due to more agricultural practices in surrounded area and illustrated in Figure 6. However Nitrate values of untreated UWW used for irrigation at three locations are safe range of restriction on use of FAO irrigation water quality standards.

\subsection{Suspended Solids (SS)}

Suspended solids indicate the amount of solids suspended in the water. High concentration of particulate matter can cause increased sedimentation and siltation in a stream.

As shown in Figure 7, the SS of untreated UWW used for irrigation shows a maximum of $300 \mathrm{mg} / \mathrm{L}$ at Station No. 1 and minimum of $40 \mathrm{mg} / \mathrm{L}$ in Station No. 3. The TDS values of untreated UWW used for irrigation at three locations largely exceeds the general standard $20 \mathrm{mg} / \mathrm{L}$ stipulated by the State Pollution Control Board for discharge of effluent on land for irrigation.

\subsection{Potassium}

Potassium is not an integral part of any major plant component but it does play a key role in a vast array of physiological processes vital to plant growth, from protein synthesis to maintenance of plant water balance. Potassium is a macro nutrient that is present in high concentrations in soils but is not bio-available since it is bound to other compounds. Generally, wastewater contains low potassium concentrations insufficient to cover the plant's theoretical demand, and use of wastewater in agriculture does not normally cause negative environmental impacts [9]. Potassium may originate from human faeces and urine disposal, as human faeces has on average 1.6\% and urine has $3.7 \%$ (dry weight) potassium. 
Nitrate (mg/l)

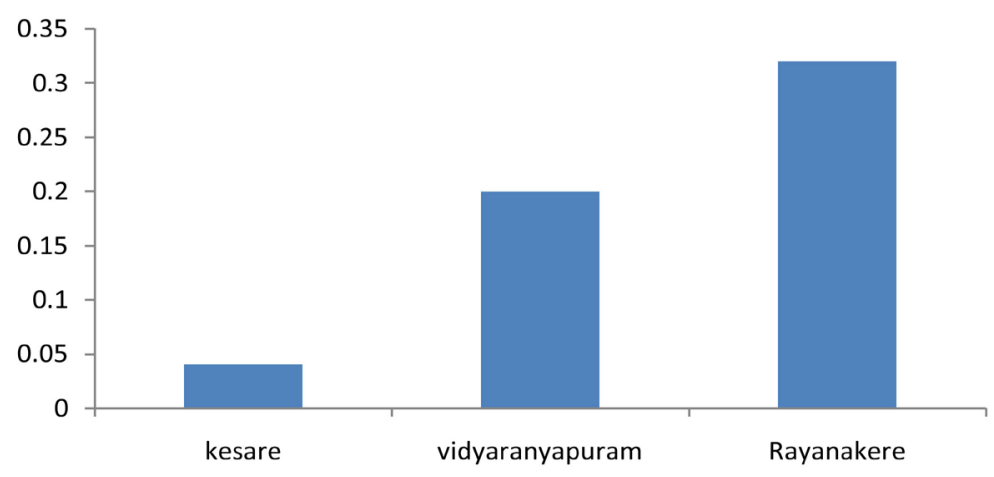

Figure 6. Nitrate of urban wastewater treatment plants.

$\mathrm{SS}(\mathrm{mg} / \mathrm{l})$

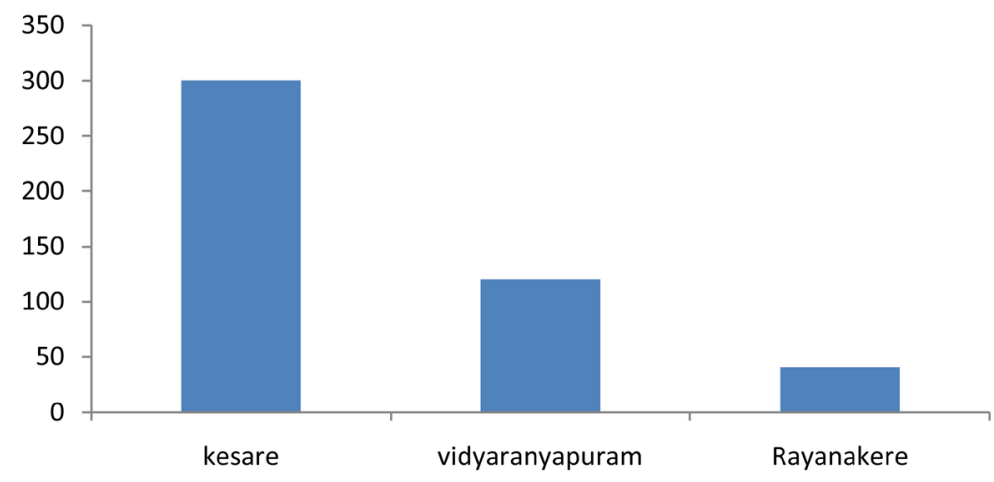

Figure 7. SS of urban wastewater treatment plants.

Figure 8 shows the concentration of Potassium in untreated UWW used for irrigation has maximum of 40 $\mathrm{mg} / \mathrm{L}$ at Station No. 1 and minimum of $17 \mathrm{mg} / \mathrm{L}$ in Station No. 3. However concentration Potassium of untreated UWW used for irrigation at three locations is exceeds of restriction on use of FAO irrigation water quality standards. The main reason may be Municipal solid waste are dumping to the UWW and concentration is depend on the amount of solid waste disposal in to a UWW.

\subsection{Phosphate $\left(\mathrm{PO}_{4}\right)$}

Phosphorus is also a primary macronutrient that is essential to the growth of plants and other biological organisms but quantities can be excessive and if the concentrations in water are too high noxious algal blooms can occur. Phosphates are classified as orthophosphates, poly-phosphates and organic phosphates. Municipal wastewaters may contain between 4 and $16 \mathrm{mg} / \mathrm{L}$ of phosphorus [10]. Wastewater with 6 - $20 \mathrm{mg} / \mathrm{L}$ Phosphorous increases the productivity of the crops and when the concentration exceeds $20 \mathrm{mg} / \mathrm{L}$ availability of Copper, Iron, and Zinc is reduced in alkaline soils.

In Figure 9, the Phosphorous of untreated UWW used for irrigation varied from $7.63 \mathrm{mg} / \mathrm{L}$ in Station No. 3 to $13.57 \mathrm{mg} / \mathrm{L}$ at Station No. 1. However values Phosphorous of untreated UWW used for irrigation at three locations are slightly exceeds but it is safe range of restriction on use of FAO irrigation water quality standards.

Wastewater normally contains low amount of Phosphorous, so its use for irrigation is beneficial and does not negative impact on the environment. This is the reason even when wastewater effluents with high concentration although, because Phosphorous builds up at the soil surface, it can affects surface waters through soil erosion and runoff.

\subsection{Biochemical Oxygen Demand (BOD)}

The Biological Oxygen Demand is an empirical test used to determine the relative oxygen requirement of water 
Potassium (mg/l)

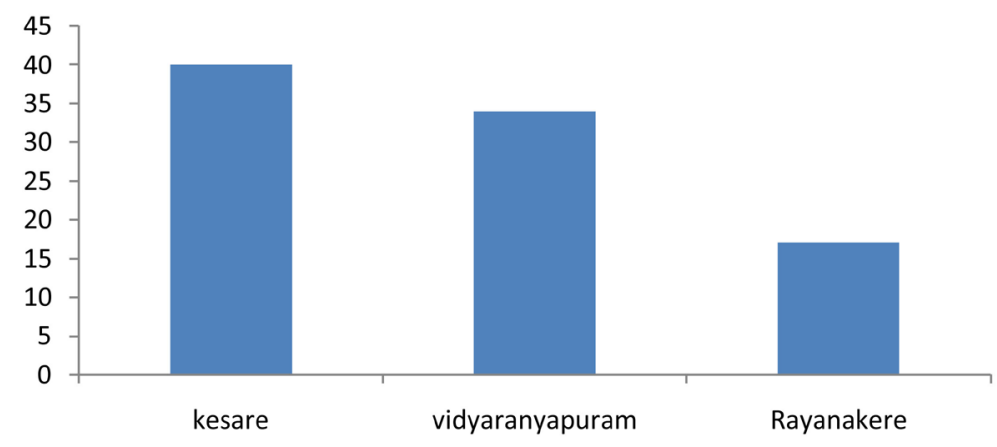

Figure 8. Potassium of urban wastewater treatment plants.

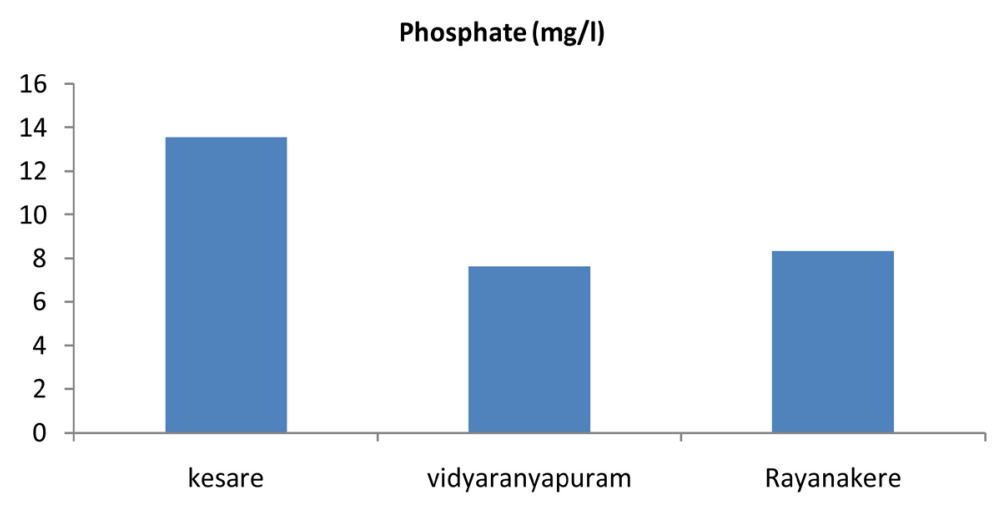

Figure 9. Phosphate of urban wastewater treatment plants.

and wastewater. To determine of BOD involves the measurement of the do used by microorganisms in the biochemical oxidation of organic matter, and measure of organic pollution.

With reference to using the UWW for irrigation, CPCB has recommended BOD of $100 \mathrm{mg} / \mathrm{L}$. WHO has recommended a standard of $<20 \mathrm{mg} / \mathrm{L}$ for irrigation of vegetables likely to be eaten uncooked. In the light of these two sets of standards restrain may be adopted for the use of untreated and treated grey water for growing vegetables, however, continuous irrigation and high organic matter contents may clog soil pores.

The BOD of untreated UWW used for irrigation showed $18.0 \mathrm{mg} / \mathrm{L}$ in Station No. 3 to $135 \mathrm{mg} / \mathrm{L}$ at Station No. 1 and 2. The BOD of untreated UWW used for irrigation exceeds the CPCB Standards. The variation of the BOD is shown in Figure 10.

\subsection{Total Heavy Metals Concentrations in UWW, Biosoilds and Soil, Used for Plant Growth}

The bioavailability of metals is directly related to the chemical characteristics of the UWW, biosolids and of the soil. Soil receiving sewage irrigation for 10 years exhibited significant increase in $\mathrm{Zn}, \mathrm{Fe}, \mathrm{Ni}$ and $\mathrm{Pb}$, while on Fe in the soils was positively affected by UWW irrigation for 5 years [11].

The long term use of biosolid can cause heavy metal accumulation in soils. Even after short-time application of biosolids, the levels of heavy metals in soils can increase considerably. Oliveira \& Mattiazzo (2001) [12] observed increases in $\mathrm{Cu}, \mathrm{Cr}, \mathrm{Ni}$ and $\mathrm{Zn}$ concentrations in soils amended for two years with biosolids. Heavy metals can also contaminate the food chain and reduce crop yields [13] [14]. The consumption of plants containing high levels of heavy metals might pose a serious risk to human health [14] [15].

Metal composition in UWW is complex and highly varying with the diversified economical activities [16] Accumulation of heavy metal in wastewater depends on many local factors. Metal input in the wastewater is always varied and cannot be predicted. Thus, with numerous sources, urban wastewater is bound to contain significant concentrations of heavy metals. 
BOD (mg/l)

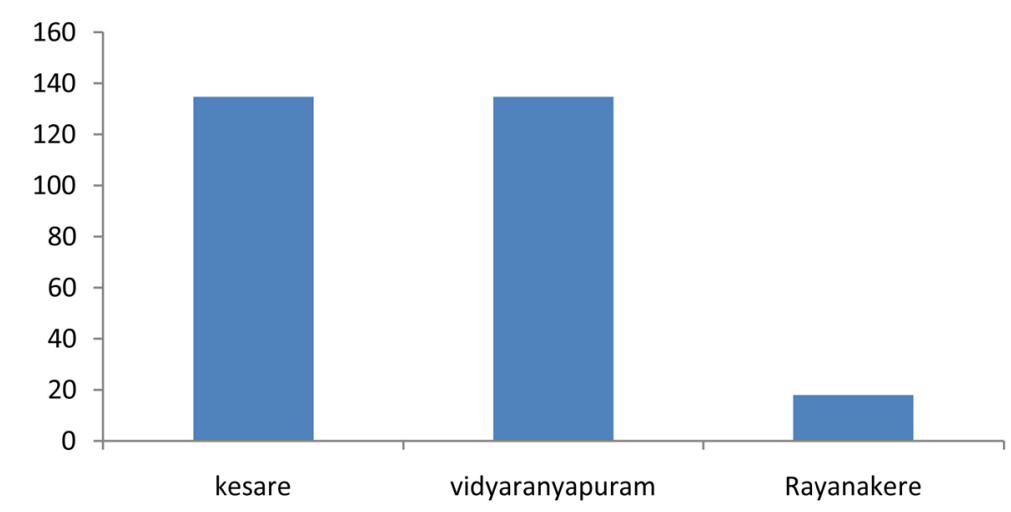

Figure 10. BOD of urban wastewater treatment plants.

The Presence of metals is crucial criteria in determining the final disposal mode of biosolids, either to agriculture or to some other. Therefore, samples of biosolids and sediment were analyzed for determination of concentration various metals viz., Cadmium, Iron, Lead, Nickel and Zinc in the sample.

\subsection{Cadmium}

During the study period the analysis of the UWW used for irrigation, biosolids, and soil amended with UWW was done. Samples of Cadmium were below detection limit, during all examined months. FAO guidelines for trace metals in irrigation waters, recommend maximum concentration of $0.01 \mathrm{mg} / \mathrm{L}$. In view of the prescribed standard it is clearly indicate that, the cadmium is well below the recommended concentration.

\subsection{Copper}

The Copper concentration in untreated UWW used for irrigation shows a $0.1 \mathrm{mg} / \mathrm{Kg}$ at Station No. 2 and 0.03 $\mathrm{mg} / \mathrm{Kg}$ at Station No. 3. Biosoild is amended with UWW is ranged from $0.07 \mathrm{mg} / \mathrm{Kg}$ in station No. 2 and BDL in station No. 3. Soil is used to grow plants is ranged from $244.7 \mathrm{mg} / \mathrm{Kg}$ in Station No. V1 and $98.3 \mathrm{mg} / \mathrm{Kg}$ in station No. 3.

As per the FAO standards, $0.2 \mathrm{mg} / \mathrm{L}$ is the recommended maximum concentration of Copper in irrigation water. The samples are well within the standards with exception during the study period. However the usage of untreated UWW directly for irrigation may be restricted.

\subsection{Iron}

The iron comes from the weathering of many iron containing minerals of the parental material of the soil. Most of soils contain an abundance of total iron, which are plants need, but many interacting factors affect and limit the iron that plants can use. An accumulation of the heavy metal Copper, manganese, zinc, and nickel in relation to available iron may induce iron deficiency in plants in acid soils.

During the study period the concentration of Iron in the untreated UWW used for irrigation ranged between $0.62 \mathrm{mg} / \mathrm{Kg}$ at Station No. 2 to $1.58 \mathrm{mg} / \mathrm{Kg}$ at Station No. 1. Biosoild is amended with UWW is ranged from $14.3 \mathrm{mg} / \mathrm{Kg}$ in Station No. 3 and $37.1 \mathrm{mg} / \mathrm{Kg}$ in Station No. 1. Soil is used for to grow plants is ranged from $1583.4 \mathrm{mg} / \mathrm{Kg}$ in Station No. 1 and $139.1 \mathrm{mg} / \mathrm{Kg}$ in Station No. 2. As per the FAO standards, $5.0 \mathrm{mg} / \mathrm{L}$ is the recommended maximum concentration of Iron in irrigation water.

\subsection{Nickel}

In the present study the concentration of Nickel in the untreated UWW used for irrigation ranged between 0.29 $\mathrm{mg} / \mathrm{Kg}$ in Station No. 2 to $0.73 \mathrm{mg} / \mathrm{Kg}$ in Station No. 1. Biosolids is amended with UWW is ranged from 0.32 $\mathrm{mg} / \mathrm{Kg}$ in station No. 3 to $0.72 \mathrm{mg} / \mathrm{Kg}$ in Station No. 1 and Soil is used for to grow plants is ranged varied from $103.1 \mathrm{mg} / \mathrm{Kg}$ in Station No. 3 to $399.2 \mathrm{mg} / \mathrm{Kg}$ in Station No. 1. In this study period the concentration of Nickel 
in UWW is well exceeds the FAO recommended maximum concentration in irrigation water standards of 0.20 $\mathrm{mg} / \mathrm{L}$.

\subsection{Lead}

The Lead concentration in untreated UWW used for irrigation varied between $0.04 \mathrm{mg} / \mathrm{Kg}$ at Station No. 2 to $0.1 \mathrm{mg} / \mathrm{Kg}$. Biosoild is amended with UWW is ranged from $0.1 \mathrm{mg} / \mathrm{Kg}$ in Station No. 1 to $0.5 \mathrm{mg} / \mathrm{Kg}$ in Station No. 3 and Soil is used for to grow plants is ranged from $9.58 \mathrm{mg} / \mathrm{Kg}$ in Station No. 3 to $21.5 \mathrm{mg} / \mathrm{Kg}$ in Station No. 1 . As per the FAO standards, $5.0 \mathrm{mg} / \mathrm{L}$ is the recommended maximum concentration of Lead in irrigation water.

\subsection{Zinc}

The Zinc concentration in untreated UWW used for irrigation shows a maximum of $0.67 \mathrm{mg} / \mathrm{Kg}$ at Station No. 3 and minimum of $0.22 \mathrm{mg} / \mathrm{Kg}$ at Station No. 1. Biosoild is amended with UWW is ranged from $1.48 \mathrm{mg} / \mathrm{Kg}$ in station No. 1 and $0.64 \mathrm{mg} / \mathrm{Kg}$ in Station No. 3. Soil is used for to grow plants is ranged from $342.6 \mathrm{mg} / \mathrm{Kg}$ in Station No. 1 and $138.1 \mathrm{mg} / \mathrm{Kg}$ in Station No. 3. As per the FAO standards, $2.0 \mathrm{mg} / \mathrm{L}$ is the recommended maximum concentration of Zinc in irrigation water.

\subsection{Heavy Metal Concentration/Uptake by Plant Samples}

The heavy metals entering the ecosystem may lead to geoaccumulation, bioaccumulation and biomagnifications and may have possibilities for environmental transformation into a toxic form. The bioavailability of metals in plants is a dynamic process that depends on specific combinations of chemical, biological and environmental parameters. These toxic heavy metals entering aquatic environment are adsorbed onto particulate matter, although they can form free metal ions and soluble complexes that are available for uptake by plants and biological organisms.

Heavy metals are potentially toxic for plants, phytotoxicity results in chlorosis, weak plant growth, yield depression and may even be accompanied by reducing the nutrient uptake, disorder in plant metabolism and in leguminous plants reducing the ability to fixate molecular nitrogen.

The bioavailability of metals is directly related to the chemical characteristics of the UWW, biosolids and of the soil. Soils receiving sewage irrigation for 10 years exhibited significant increase in $\mathrm{Zn}, \mathrm{Fe}, \mathrm{Ni}$ and $\mathrm{Pb}$, while on Fe in the soils was positively affected by sewage irrigation for 5 years [11].

The long-term use of sludge can cause heavy metal accumulation in soils [17]. Even after short-time application of biosolids, the levels of heavy metals in soils can increase considerably, Oliveira et al. (2001) [12] observed increases in $\mathrm{Cu}, \mathrm{Cr}, \mathrm{Ni}$ and $\mathrm{Zn}$ concentrations in soils amended for two years with biosolids. Heavy metals can also contaminate the food chain and reduce crop yields [13] [14].

The consumption of plants containing high levels of heavy metals might pose a serious risk to human health [14] [15]. The analysis of Total metal concentration/Uptake of heavy metal in the plant species samples to grow using UWW, Biosoild, Soil, were analyzed by adopting Standard Analytical procedure mentioned in Materials and Method Chapter.

\subsection{Uptake of Heavy Metal by Plants in Kesare, Mysore}

The plant species were identified and collected for the analysis of heavy metal uptake. Heavy metals such as Cd, $\mathrm{Cu}, \mathrm{Fe}, \mathrm{Ni}, \mathrm{Pb}$, and $\mathrm{Zn}$ were analyzed for all the plant species. Most of all metals were detected in the plants except Cd. Lead was detected only in P. purpureum species having the concentration of $4.6 \mathrm{mg} / \mathrm{Kg}$. The Iron uptake was varied from $123.3 \mathrm{mg} / \mathrm{Kg}$ to $683.1 \mathrm{mg} / \mathrm{Kg}$, for $\mathrm{Ni}$ it was $0.32 \mathrm{mg} / \mathrm{Kg}$ to $8.2 \mathrm{mg} / \mathrm{Kg}$ and Cu uptake for the plants ranged between $0.1 \mathrm{mg} / \mathrm{Kg}$ to $6.3 \mathrm{mg} / \mathrm{Kg}$. The highest amount of uptake was seen in $P$. purpureum species for all the metals in the treatment plant.

\subsection{Uptake of Heavy Metal by Plants in Sewage Farm, Vidhyaranyapuram, Mysore}

The concentration of Cadmium was not detected in any of the plant species. The Lead was detected only in $P$. purpureum species with the concentration of $3.6 \mathrm{mg} / \mathrm{Kg}$. For the uptake of $\mathrm{Cu}$ was estimated and it was found 
with the range of $0.06 \mathrm{mg} / \mathrm{Kg}$ to $5 \mathrm{mg} / \mathrm{Kg}$ in Spiracia oleracea and $P$. purpureum respectively. Iron uptake was varied from $106.9 \mathrm{mg} / \mathrm{Kg}$ to $412.2 \mathrm{mg} / \mathrm{Kg}$, for $\mathrm{Ni}$ it was $0.78 \mathrm{mg} / \mathrm{Kg}$ to $7.8 \mathrm{mg} / \mathrm{Kg}$ and $\mathrm{Zn}$ uptake were found with the $0.6 \mathrm{mg} / \mathrm{Kg}$ to $30.2 \mathrm{mg} / \mathrm{Kg}$.

\subsection{Uptake of Heavy Metal by Plants in Sewage Farm, Rayanakere, Mysore}

The Cadmium and Lead was not detected in any plant species grown in Rayanakere treatment plant since the availability of the metal in the UWW, soil, biosoild has very low in concentration compare to other metals.

Heavy metals such as $\mathrm{Cu}, \mathrm{Fe}, \mathrm{Ni}$ and $\mathrm{Zn}$ were successfully uptake by the plants which indicates the accumulation process in the plant body. The $\mathrm{Cu}$ ranges between $0.07 \mathrm{mg} / \mathrm{Kg}$ to $4.9 \mathrm{mg} / \mathrm{Kg}$ in Coriandrum sativum and $P$. purpureum respectively. Iron was found in the concentration of $86.2 \mathrm{mg} / \mathrm{Kg}$ to $573 \mathrm{mg} / \mathrm{Kg}$, Ni uptake was 0.39 $\mathrm{mg} / \mathrm{Kg}$ to $4.9 \mathrm{mg} / \mathrm{Kg}$ and $\mathrm{Zn}$ uptake was $0.7 \mathrm{mg} / \mathrm{Kg}$ to $40.3 \mathrm{mg} / \mathrm{Kg}$. The $P$. purpureum species showed the highest concentration of metal uptake during the study period. The study clearly shows plant species grown in the month of March was maximum it may be due to scarcity of water and concentration of heavy metals would be more.

\section{Conclusion}

Water is one of the important natural resources. In the agricultural field water plays an important role in the growth and yield of the plants. In this aspect, the conservation of water resources should be needed. In the wastewater treatment plant of Mysore receives huge amount of wastewater by the urban sector. To minimize the raw water consumption for the agriculture field proper treatment should be done. In the present study the analyzed parameters showed higher amount of COD and BOD in untreated wastewater in all the three treatment plants of Mysore city, which exceed the CPCB permissible limit for disposing the UWW on land for irrigation. But EC and TDS are within the range of the FAO irrigation water quality standards. Presence of high amount of heavy metals in the untreated wastewater would result in the pollution by entering into water bodies and soil through agricultural practices. Seasonal variations act upon a number of factors that influence the toxicity of UWW and its effects in the receiving environment. The factors affected include dissolved oxygen in receiving water body, temperature of the wastewater and the receiving environment. The presence of Nitrate, Phosphate and Potassium (NPK) indicates the nutrient level in the wastewater. The presence of these nutrients can be beneficial for the use of agricultural field and it can minimize the water scarcity for agriculture purposes. In the present study it reveals the heavy metal uptake by the plant species which were grown using wastewater and indicating the mobility of heavy metal in the soil environment. Due to its mobility it results with the bio accumulation and biomagnification process in the nature.

\section{References}

[1] United Nation's World Water Development Report (2003) UN World Water Development Report: Water for People, Water for Life. UNESCO and Berghahn Books, Paris, New York, Oxford.

[2] Marshall, F. and Sharma, R. (2006) Waste Water Irrigation and Heavy Metal Contamination in Peri-Urban India. Geophysical Research Abstracts, 8, Article ID: 09058.

[3] Soulié, M. and Tréméa, L. (1991) Technologie pour le traitement et la réutilisation des eaux usées dans le bassin méditerranéen. Proceedings of the 3rd Meeting of the Regional Agency for Environment, Provence, 171-255.

[4] AATSE-Australian Academy of Technological Sciences and Engineering (2004) Water Recycling in Australia. AATSE, Victoria.

[5] Jiménez, B. and Asano, T. (2008) Water Reclamation and Reuse around the World. In: Jiménez, B. and Asano, T., Eds., Water Reuse: An International Survey of Current Practice, Issues and Needs, IWA Publishing, London, 648.

[6] Keraita, B.N., Jiménez, B. and Drechsel, P. (2008) Extent and Implications of Agricultural Reuse of Untreated, Partly Treated and Diluted Wastewater in Developing Countries. CAB Reviews: Perspectives in Agriculture, Veterinary Science, Nutrition and Natural Resources, L3, 1-15. http://dx.doi.org/10.1079/PAVSNNR20083058

[7] Bai, S., Srikantaswamy, S. and Shivakumar, D. (2010) Urban Wastewater Characteristic and Its Management in Urban Areas-A Case Study of Mysore City, Karnataka, India. Journal of Water Resource and Protection, 2, 717-726. http://dx.doi.org/10.4236/jwarp.2010.28082

[8] Pescod, M.B. (1992) Wastewater Treatment and Use in Agriculture. Food and Agriculture Organization (FAO), Irrigation and Drainage Paper, 73. 
[9] Mikkelsen, R. and Camberato, J. (1995) Potassium, Sulfur, Lime and Micronutrient Fertilizers. In: Rechcigl, J., Ed., Soil Amendments and Environment Quality, Lewis Publishing, Boca Raton, 109-137.

[10] Asano, T., Burto, F.L., Leveren, H.L., Suchihashi, R. and Tchobanoglous, G. (2003) Wastewater Engineering Treatment and Reuse. 4th Edition, McGraw Hill, New York.

[11] Rattan, R.K., Datta, S.P., Chhonkar, P.K., Suribabu, K. and Singh, A.K. (2005) Long-Term Impact of Irrigation with Sewage Effluent on Heavy Metal Content in Soils, Crops and Groundwater-A Case Study. Agriculture, Ecosystems \& Environment, 109, 310-322.

[12] Oliveira, F.C. and Mattiazzo, M.E. (2001) Metais pesadosem Latossolo tratado com lodo de esgoto e emplantas de cana-de-açúcar. Scientia Agricola, 58, 581-593. http://dx.doi.org/10.1590/S0103-90162001000300022

[13] Obrador, A., Rico, M.I., Mingot, J.I. and Alvarez, J.M. (1997) Metal Mobility and Potential Bioavailability in Organic Matter-Rich Soil-Sludge Mixtures: Effect of Soil Type and Contact Time. Science of the Total Environment, 206, 117-126.

[14] Wang, C., Li, X.C., Ma, H.T., Qian, J. and Zhai, J.B. (2003) Distribution of Extractable Fractions of Heavy Metals in Sluges during the Waste Treatment Process. Journal of Hazardous Materials, 137, 1277-1283.

[15] Turkdogan, M.K., Kilicel, F., Kara, K., Tuncer, I. and Uygan, I. (2003) Heavy Metals in Soil, Vegetables and Fruits in the Endemic Upper Gastrointestinal Cancer Region of Turkey. Environmental Toxicology and Pharmacology, 13, 175179. http://dx.doi.org/10.1016/S1382-6689(02)00156-4

[16] Oliveira, A., Bocio, A., Trevilato, T.M.B., Takayanagui, A.M.M., Domingo, J.L. and Segura-Munoz, S.I. (2007) Heavy Metals in Untreated/Treated Urban Effluent and Sludge from a Biological Wastewater Treatment Plant. Environmental Science and Pollution Research, 14, 483-489. http://dx.doi.org/10.1065/espr2006.10.355

[17] López-Mosquera, M.E., Moirón, C. and Carral, E. (2000) Use of Dairy-Industry Sludge as Fertilizer for Grasslands in Northwest Spain: Heavy Metal Level in the Soil and Plant. Resources, Conservation and Recycling, 30, 95-109. http://dx.doi.org/10.1016/S0921-3449(00)00058-6 
Scientific Research Publishing (SCIRP) is one of the largest Open Access journal publishers. It is currently publishing more than 200 open access, online, peer-reviewed journals covering a wide range of academic disciplines. SCIRP serves the worldwide academic communities and contributes to the progress and application of science with its publication.

Other selected journals from SCIRP are listed as below. Submit your manuscript to us via either submit@scirp.org or Online Submission Portal.
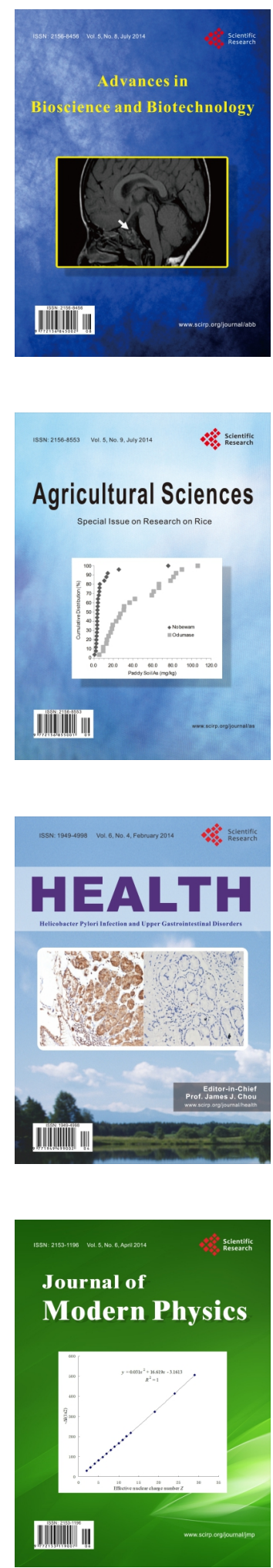
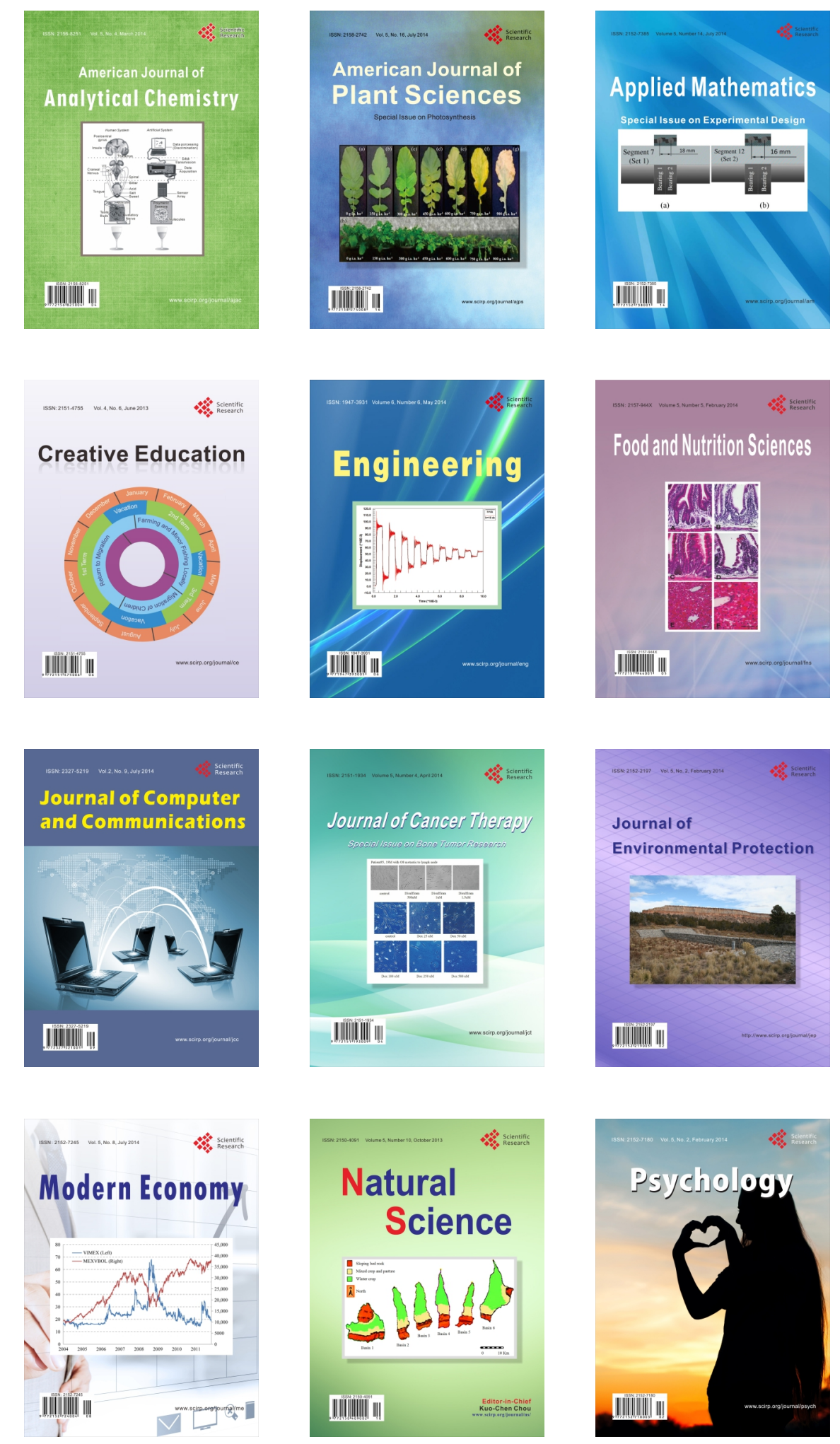